\title{
STRUKTUR KOMUNITAS FITOPLANKTON PADA PERAIRAN MAYANGAN PROBOLINGGO, JAWA TIMUR
}

\author{
Felixtha Robertus Ginting ${ }^{a}$, Dwi Candra Pratiwi ${ }^{a}$, Erfan Rohadi ${ }^{c}$, Nurul Muslihah ${ }^{d}$, Dian Aliviyanti ${ }^{\mathrm{a}}$ \\ Aida Sartimbul ${ }^{\mathrm{a}, \mathrm{b}, *}$
}

${ }^{a}$ Fakultas Perikanan dan Ilmu Kelautan, Universitas Brawijaya Jalan Veteran Malang 65145, Indonesia

${ }^{b}$ Marine Resources Exploration and Management (MEXMA) Research Group, Fakultas Perikanan dan Ilmu Kelautan, Universitas Brawijaya, Jalan Veteran, Malang 65145, Indonesia

${ }^{c}$ State Polytechnic of Malang, Jalan Sukarno-Hatta No. 9, Malang 65141, Indonesia

${ }^{\mathrm{d}}$ Faculty of Medicine, Brawijaya University, Jalan Veteran, Malang 65145

*Koresponden penulis: aida@ub.ac.id

\begin{abstract}
Abstrak
Perairan Mayangan, Probolinggo merupakan perairan yang memiliki pelabuhan dengan stasus Pelabuhan Perikanan Pantai (PPP). Keberadaan PPP Mayangan yang sangat padat akan aktifitas perikanan yang meliputi penangkapan, pengolahan ikan, dan pariwisata dapat memberikan dampak negatif pada kualitas air yang ada di perairan ini. Sebagai produsen primer, keberadaan fitoplankton sangat tergantung pada kondisi lingkungan perairan tersebut. Penelitian ini bertujuan untuk mengetahui struktur komunitas fitoplankton dan hubungannya dengan kondisi kualitas Perairan Mayangan, Probolinggo. Sampel fitoplankton diambil dengan menggunakan plankton net kitahara berukuran $50 \mu \mathrm{m}$. Pada waktu yang bersamaan sampel kualitas air juga diambil dengan masing-masing 3 kali pengulangan. Hasil penelitian menunjukkan nilai rata-rata suhu sebesar $36,8 \pm 1,40^{\circ} \mathrm{C}$, pH 7,2 $\pm 0,07$, salinitas $33,5 \pm 0,58 \mathrm{ppt}$, kecerahan $6,5 \pm 0,66 \mathrm{~m}$, nitrat $0,023 \pm 0,010 \mathrm{mg} / \mathrm{L}$, fosfat $0,022 \pm 0,020 \mathrm{mg} / \mathrm{L}$. Fitoplankton yang dominan ditemukan adalah Chaetoceros dan Skeletonema, kedua genus ini tergolong sebagai Harmful Algal Bloom (HAB). Analisis korelasi Pearson menunjukkan nilai kecerahan berkorelasi positif dengan kelimpahan fitoplankton di Perairan Mayangan, Probolinggo. Pemantauan fitoplankton secara terus menerus dan rutin pada perairan Mayangan sangat diperlukan dalam menjaga keberlanjutan sumberdaya Perairan Mayangan dan sekitarnya.
\end{abstract}

Kata kunci: Bioindikator, Fitoplankton, Kualitas air, Mayangan.

\begin{abstract}
The waters of Mayangan, Probolinggo are waters that have a port with a coastal fishery port (Perlabuhan Perikanan Pantai: PPP) status. The existence of PPP Mayangan which is very dense in fishery activities which includes fishing, fish processing, and tourism can have a negative impact on the quality of water in these waters. As a primary producer the existence of phytoplankton is very dependent on the environmental conditions of the waters. This study aims to determine the community structure of the phytoplankton and its relationship with the water quality of Mayangan waters, Probolinggo. Phytoplankton samples were taken using $50 \mu \mathrm{m}$ of kitahara plankton net. At the same time water quality samples were also taken with 3 repetitions each. The results showed that the average temperature was $36.8 \pm 1.40^{\circ} \mathrm{C}, \mathrm{pH} 7.2 \pm 0.07$, salinity $33.5 \pm 0.58 \mathrm{ppt}$, brightness $6.5 \pm 0.66 \mathrm{~m}$, nitrate $0.023 \pm 0.010 \mathrm{mg} / \mathrm{L}$, phosphate $0.022 \pm 0.020 \mathrm{mg} / \mathrm{L}$. The dominant phytoplankton found are Chaetoceros and Skeletonema, both genera are classified as Harmful Algae Bloom (HAB). Pearson correlation analysis shows that the transparancy value has a positive correlation with the abundance of phytoplankton in Mayangan waters, Probolinggo. Continuous and routine monitoring of phytoplankton in Mayangan waters is very necessary in maintaining the sustainability of the Mayangan marine resources and its surroundings.
\end{abstract}

Keywords: Bioindicator, Phytoplankton, Water quality, Mayangan. 


\section{PENDAHULUAN}

Kota Probolinggo merupakan kota yang memiliki panjang garis pantai sepanjang $7 \mathrm{~km}$ dan wilayah perairan sepanjang $20 \mathrm{~km}$ [1] Perairan Pantai Mayangan memiliki potensi sumberdaya perikanan yang cukup melimpah dan memiliki nilai ekonomi yang tinggi. Hal ini didukung pula dengan adanya Pelabuhan Perikanan Pantai (PPP) Mayangan, sehingga meningkatkan aktifitas perikanan yang ada di daerah tersebut. Jumlah kapal yang berlabuh di pelabuhan Probolinggo terus mengalami peningkatan yang signifikan, misalnya pada tahun 2015 dan 2017, sebanyak 175 kapal meningkat tajam menjadi 1551 kapal. Meskipun meningkatkan ekonomi, namun demikian aktifitas perikanan yang cukup padat menjadi ancaman bagi kualitas perairan pantai berupa polusi dari berbagai aktifitas pelabuhan seperti bongkar muat kapal, kebocoran bahan bakar, limbah pengolahan ikan, limbah dari pemukiman penduduk dan lain-lain.

Pemantauan fitoplankton pada suatu perairan menjadi salah metode yang umum dipakai dan relatif mudah dan murah untuk mengetahui kesehatan lingkungan perairan, karena sifat fitoplankton yang sensitif terhadap perubahan lingkungan [2]. Fitoplankton merupakan produsen primer dan penyumbang oksigen terlarut dalam suatu perairan. Fitoplankton merupakan organisme autotrof yang berukuran mikroskopis dan dapat menghasilkan bahan organik dari bahan anorganik melalui proses fotosintesis [3]. Keberadaannya dapat dijadikan sebagai indikator kesuburan suatu perairan [4]. Bioindikator atau indikator biologi dapat berupa individu ataupun populasi hewan, tumbuhan, atau organisme mikroskopis yang keberadaan dan vitalitasnya sangat mudah dipengaruhi oleh perubahan lingkungan [5]. Sebagai bioindikator kesuburan perairan dan sensitif terhadap perubahan lingkungan maka keberadaan organisme ini menjadi sangat penting di perairan.

Berbagai aktifitas di Pelabuhan Mayangan dan keterbatasan informasi terkini tentang fitoplankton di daerah ini menjadi alasan dilakukannya pemantauan struktur komunitas fitoplankton di Perairan Mayangan. Tujuan dari penelitian adalah untuk mengetahui struktur komunitas fitoplankton dan hubungannya dengan kondisi kualitas perairan Perairan Mayangan. Melalui penelitian ini diharapkan dapat digunakan sebagai salah satu dasar pertimbangan dalam pengelolaan Perairan Mayangan, Probolinggo, Jawa Timur secara berkelanjutan.

\section{METODE PENELITIAN}

Penelitian ini dilakukan pada bulan Mei 2019 di Perairan Mayangan, Probolinggo, Jawa Timur. Metode purposive sampling digunakan dalam penentuan lokasi sampling. Stasiun 1 mewakili daerah Pelabuhan Mayangan Probolinggo, stasiun 2 dan 3 mewakili daerah fishing ground, dan stasiun 4 mewakili daerah budidaya ikan (Gambar 1).

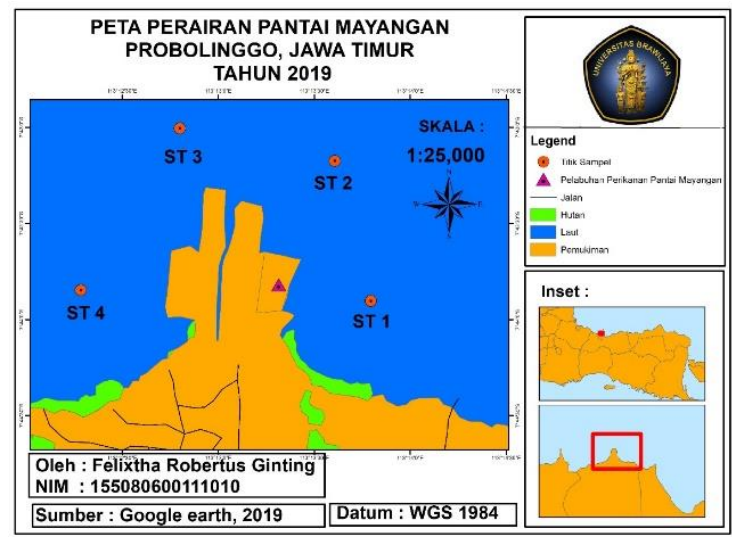

Gambar 1. Peta Perairan Mayangan dengan 4 stasiun pengambilan sampel: St.1, St.2, St.3, dan St.4. yang ditentukan dengan metode purposive sampling. (St.: Stasiun pengambilan sampel)

Sampel fitoplankton diambil menggunakan plankton net kitahara dengan ukuran mesh sebesar $50 \mu \mathrm{m}$ dengan cara menyaring $100 \quad \mathrm{~L}$ air dengan 3 kali pengulangan. Selanjutnya sampel fitoplankton diawetkan dengan menggunakan lugol 1\% dan dimasukkan ke dalam coolbox berisi es untuk untuk kemudian dikirim ke laboratorium Hidrologi, Fakultas Perikanan dan Ilmu Kelautan, Universitas Brawijaya, Malang untuk dilakukan pengamatan serta perhitungan sampel fitoplankton. Adapun nilai yang dihitung yaitu nilai indeks kelimpahan fitoplankton dengan menggunakan metode Lackey Drop Macrotransect Counting, nilai keanekaragaman (Shanon-Wiener/ H'), keseragaman (E), dan dominansi (D) [6]. Parameter kualitas air juga diukur secara langsung meliputi suhu, salinitas, $\mathrm{pH}$, dan kecerahan. Sedangkan parameter nitrat dan 
fosfat dianalisis menggunakan spectrometer yang dilakukan di laboratorium Hidrobiologi Fakultas Perikanan dan Ilmu Kelautan Universitas Brawijaya, Malang. Analisis hubungan kelimpahan fitoplankton dengan parameter kualitas air dianalisis menggunakan Korelasi Pearson, selanjutnya dilakukan analisis Clustering untuk melihat terkelompoknya pola kemiripan atau ketidakmiripan di masing-masing stasiun. Kedua analisis statistik tersebut menggunakan aplikasi Statistical Package for the Social Sciences (SPSS). Adapun standar baku mutu perairan mengacu pada Keputusan Menteri Negara Lingkungan Hidup Nomor 51 tahun 2004.

\section{HASIL DAN PEMBAHASAN}

\section{Nilai Kualitas Air}

Hasil pengukuran nilai kualitas air di Perairan Mayangan, Probolinggo dapat dilihat pada Tabel 1. Berdasarkan hasil yang diperoleh, nilai parameter $\mathrm{pH}$, salinitas, dan kecerahan masih dalam ambang batas baku mutu yang ditetapkan. Sedangkan parameter suhu, nitrat dan fosfat menunjukkan nilai yang melebihi ambang batas baku mutu berdasarkan Keputusan Menteri Lingkungan Hidup No.51 Tahun 2004 tentang Baku Mutu Air Laut terutama peruntukan wisata bahari dan biota laut.

Parameter $\mathrm{pH}$ dan salinitas pada keempat stasiun memiliki nilai yang hampir sama yaitu dengan rata-rata nilai $\mathrm{pH} 7,2 \pm 0,07$ dan salinitas $33,5 \pm 0,58$ ppt. Menurut [7], kisaran $\mathrm{pH}$ yang baik untuk kehidupan fitoplankton adalah 6,5. Organisme yang menjadi makanan alami ikan tidak dapat hidup pada perairan yang memiliki $\mathrm{pH}$ kurang dari 6 atau berkondisi asam. Perubahan nilai $\mathrm{pH}$ di suatu perairan dapat mempengaruhi proses kimia, biologis organisme, dan toksisitas senyawa kimia di perairan [8].

Nilai salinitas menunjukkan nilai yang cukup konstan dengan nilai rata-rata yang ditemukan adalah sebesar 33,5 $\pm 0,58$ ppt. Menurut [9], kadar salinitas di suatu tempat dipengaruhi oleh letak geografis dan waktu, fluktuasi nilai salinitas pada suatu area terjadi karena adanya presipitasi dan masukan air tawar dari sungai sedangkan peningkatan salinitas terjadi karena adanya evaporasi serta terjadinya pembekuan es di laut.

Selanjutnya nilai kecerahan yang diperoleh cukup bervariasi dengan rata-rata $6,5 \pm 0,66 \mathrm{~m}$ dari keempat stasiun. Stasiun 3 memiliki nilai kecerahan tertinggi yaitu sebesar 10,5 $\pm 1,15 \mathrm{~m}$, sedangkan yang terendah pada stasiun 1 dan 4 sebesar $4 \pm 0,25 \mathrm{~m}$. Menurut [10], tingkat kecerahan perairan dipengaruhi oleh tingkat intensitas cahaya matahari yang mampu menembus suatu perairan. Ditambahkan oleh [11], faktor yang mempengaruhi kecerahan adalah jumlah partikel terlarut dan partikel tersuspensi yang ada di dalam suatu perairan. Semakin tinggi jumlah partikel terlarut maupun tersuspensi, maka semakin rendah nilai kecerahan suatu perairan

Hal ini juga dapat dipengaruhi oleh lokasi stasiun pengamatan sebagai contoh pada stasiun 1 merupakan lokasi terdekat dengan Pelabuhan Mayangan dan stasiun 4 merupakan lokasi yang dimanfaatkan untuk aktivitas budidaya ikan. Semakin tinggi aktivitas manusia pada suatu perairan menyebabkan kekeruhan air meningkat. [12] yang menyatakan bahwa kecerahan perairan yang rendah menggambarkan nilai kekeruhan yang tinggi.

Selanjutnya nilai rata-rata parameter suhu di Perairan Mayangan adalah sebesar $36,8 \pm 1,40^{\circ} \mathrm{C}$. Berdasarkan KEPMEN LH No. 51 Tahun 2004 nilai baku mutu suhu untuk

Tabel 1. Hasil pengukuran kualitas air Mayangan Probolinggo

\begin{tabular}{ccccccc}
\hline Stasiun & Suhu $\left({ }^{\circ} \mathbf{C}\right)$ & $\mathbf{p H}$ & Salinitas $(\mathbf{p p t})$ & Kecerahan $(\mathbf{m})$ & $\begin{array}{c}\text { Nitrat } \\
(\mathbf{m g} / \mathbf{L})\end{array}$ & $\begin{array}{c}\text { Fosfat } \\
(\mathbf{m g} / \mathbf{L})\end{array}$ \\
\hline 1 & $35,9 \pm 1,18$ & $7,3 \pm 0,15$ & $33,7 \pm 0,58$ & $4,0 \pm 0,66$ & $0,022 \pm 0,002$ & $0,038 \pm 0,023$ \\
2 & $35,7 \pm 1,13$ & $7,2 \pm 0,03$ & $33,7 \pm 0,58$ & $7,4 \pm 0,58$ & $0,028 \pm 0,010$ & $0,015 \pm 0,002$ \\
3 & $37,2 \pm 1,16$ & $7,1 \pm 0,04$ & $33,3 \pm 0,58$ & $10,5 \pm 1,15$ & $0,015 \pm 0,009$ & $0,021 \pm 0,018$ \\
4 & $38,2 \pm 2,14$ & $7,2 \pm 0,05$ & $33,3 \pm 0,58$ & $4,0 \pm 0,25$ & $0,025 \pm 0,007$ & $0,016 \pm 0,001$ \\
Rata-rata & $36,8 \pm 1,40$ & $7,2 \pm 0,07$ & $33,5 \pm 0,58$ & $6,5 \pm 0,66$ & $0,023 \pm 0,010$ & $0,022 \pm 0,020$ \\
Baku Mutu & Alami & $7-8.5$ & $33-34$ & $>6$ & 0,008 & 0,015 \\
\hline
\end{tabular}


perairan pelabuhan adalah tergolong suhu alami yaitu kondisi normal lingkungan yang bervariasi terpengaruh waktu (pagi, siang, dan malam). Suhu permukaan laut sangat dipengaruhi oleh jumlah panas yang diterima dari matahari [13]. Pengukuruan nilai kualitas air pada penelitian ini yang dilakukan pada pukul 10.00 sampai 14.00 WIB menunjukkan penetrasi cahaya yang tinggi. Kenaikan suhu permukaan laut pada dasarnya menyebabkan peningkatan laju metabolisme biota, termasuk aktivitas fotosintesis fitoplankton yang pada akhirnya akan menyebabkan meningkatnya kelimpahan fitoplankton, namun peningkatan suhu permukaan laut yang berlebihan dapat menyebabkan keseimbangan ekosistem terganggu [14].

Parameter kimia selanjutnya adalah nitrat dan fosfat. Masing-masing rata-rata nilai parameter tersebut adalah $0,023 \pm 0,010$ dan $0,022 \pm 0,020 \mathrm{mg} / \mathrm{L}$. KEPMEN LH No. 51 Tahun 2004 tidak menetapkan parameter nitrat dan fosfat sebagai parameter yang perlu dipantau kadarnya untuk perairan pelabuhan. Namun pengamatan terhadap dua parameter tersebut sangat berkaitan dengan kelimpahan fitoplankton pada lingkungan.

Menurut [15], nitrogen dalam perairan berperan sebagai elemen pembatas pertumbuhan fitoplankton di dalam suatu perairan. Umumnya pemanfaatan nitrat oleh organisme bertujuan untuk pembentukan biomassa, sebagai komponen asam amino, dan berbagai protein dari hasil sintesis [16]. Pada penelitian ini kadar nitrat tertinggi terjadi pada stasiun 2 yaitu dengan nilai $0,028 \pm 0,010 \mathrm{mg} / \mathrm{L}$ dan diketahui wilayah ini merupakan daerah fishing ground. Tingginya kadar nitrat menunjukkan tingkat kesuburan perairan yang tinggi pula dan bermanfaat untuk penunjang kehidupan fitoplankton. Menurut [17], fitoplankton dapat melakukan pertumbuhan dengan baik pada kisaran nitrat $0,028-0,140$ $\mathrm{mg} / \mathrm{L}$.

Selanjutnya nilai fosfat tertinggi yaitu $0,038 \mathrm{mg} / \mathrm{L}$ terjadi pada stasiun 1 . Tingginya nilai fosfat pada stasiun ini dapat disebabkan adanya aktifitas manusia di wilayah pelabuhan. Fosfat di perairan dapat bersumber dari alam ataupun antropogenik seperti limbah pertanian, limbah industri, limbah perikanan, serta limbah rumah tangga (detergen) [18]. Organisme memanfaatkan fosfat karena perannya sebagai komponen asam nukleat yang mengatur sintesis protein dan transformasi adenosine fosfat sebagai sumber energi dalam transpor intraselular [19]. Kisaran nilai fosfat yang baik untuk pertumbuhan fitoplankton sebesar 27 $55 \mu \mathrm{g} / \mathrm{L}[20]$.

\section{Struktur Komunitas Fitoplankton}

\section{Komposisi Fitoplankton di Perairan Mayangan, Probolinggo}

Berdasarkan hasil penelitian ini, fitoplankton yang ditunjukkan pada Gambar 2 terdiri dari 4 (empat) divisi yaitu Bacillariophyta, Dinoflagellata, Cyanophyta, dan Ochrophyta. Adapun jumlah yang ditemukan pada kelas Bacillariophyceae sebanyak 30 genus, divisi Dinoflagellata sebanyak 8 genus, pada divisi Cyanophyta dan Ochrophyta masing-masing hanya ditemukan 1 genus. Genus fitoplankton yang ditemukan paling banyak pada penelitian ini adalah genus Bacillariophyta.

Nilai kelimpahan fitoplankton yang diperoleh berturut-turut dari stasiun 1 sampai dengan 4 sebesar $2599 \mathrm{sel} / \mathrm{ml}, 2234 \mathrm{sel} / 1,1528$ sel/ 1, dan $2575 \mathrm{sel} / \mathrm{ml}$. Fitoplankton dari divisi Bacillariophyta ditemukan paling dominan. Hal ini dikarenakan fitoplankton dari divisi ini memiliki daya tahan dan kemampuan yang baik dalam beradaptasi pada lingkungan. Oleh karena itu, fitoplankton dari divisi Bacillariophyta banyak ditemukan melimpah di suatu perairan [21],[22].

Nilai kelimpahan fitoplankton tertinggi berada pada stasiun 1 dengan nilai kelimpahan sebesar $2599 \mathrm{sel} / \mathrm{ml}$ dan terendah pada stasiun 3 sebesar $1528 \mathrm{sel} / \mathrm{ml}$. Stasiun 1 terletak di dekat pelabuhan sehingga pada stasiun ini memiliki potensi masukan limbah pelabuhan lebih tinggi daripada stasiun lainnya. Hal ini

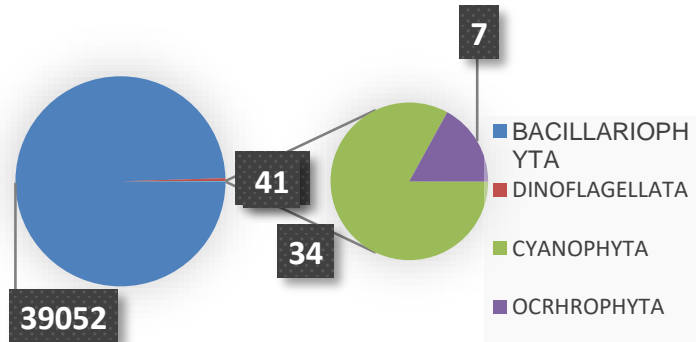

Gambar 2. Divisi fitoplankton yang teridentifikasi ( $\mathrm{sel} / \mathrm{ml})$. 
diketahui dari tingginya kadar fosfat pada stasiun ini, bila dibandingkan dengan stasiun lainnya. Penambahan kadar fosfat sebesar 0,6 - 0,7 mg/L pada media alami mampu mendukung pertumbuhan Oscillatoria, jenis fitoplankton CyanoHABs (Cyanobacteria Harmful Algae Blooms) [23].

\section{Indeks Biologi $\left(H^{\prime}, E, D\right)$}

Nilai keanekaragaman (H') fitoplankton yang ditemukan di Perairan Mayangan yaitu pada stasiun 1 sebesar 1,58 , pada stasiun 2 sebesar 1,68, stasiun 3 sebesar 1,43 dan stasiun 4 sebesar 1,55 . Nilai keanekaragam tertinggi berada pada stasiun 2 yaitu sebesar 1,68 dan yang terendah pada stasiun 3 sebesar 1,43. Nilai indeks keanekaragaman pada Perairan Mayangan ini berada diantara 1 dan 3. Menurut [24], keanekaragaman fitoplankton yang masuk dalam rentang $1<\mathrm{H}^{-}<3$ memiliki keragaman jenis yang sedang.

Berdasarkan hasil nilai indeks biologi (D) fitoplankton (Tabel 2) dapat dilihat bahwa nilai indeks dominansi fitoplankton paling tinggi adalah pada stasiun 1 dan 4 yaitu sebesar 0,30 dan terendah sebesar 0,25 pada stasiun 2 . Nilai indeks dominansi yang nilainya berada pada rentang $0<\mathrm{C} \leq 0,5$ masuk dalam kriteria dominansi rendah. Semakin besar nilai indeks dominansi maka dapat diindikasikan semakin besar pula kecenderungan adanya salah satu jenis tertentu yang mendominasi populasi [24].

Genus paling dominan dari divisi Bacillariophyta yang ditemukan pada penelitian ini adalah genus Chaetoceros dan genus Skeletonema. Fitoplankton yang termasuk dalam genus skeletonema dan chaetoceros merupakan fitoplankton yang termasuk dalam jenis Harmful Alga Bloom (HAB). Terjadinya blooming Skeletonema sp. sangat perlu diwaspadai karena Skeletonema sp. dapat menyebabkan gangguan pernapasan pada beberapa biota seperti ikan [21]. Sedangkan Chaetoceros sp. memiliki duri dengan gigi-gigi tajam yang dapat tersangkut pada jaringan tisu pada insang ikan sehingga menyebabkan terjadinya iritasi yang merangsang terciptanya lender pada insang ikan [25].
Tabel 2. Nilai indeks biologi fitoplankton

\begin{tabular}{ccccc}
\hline \multirow{2}{*}{ Stasiun } & \multicolumn{4}{c}{ Indeks Biologi (Rataan) } \\
\cline { 2 - 5 } & $\begin{array}{c}\mathbf{N} \\
\text { (sel/ml) }\end{array}$ & $\mathbf{H}^{\prime}$ & D & E \\
\hline St1 & 2599 & 1,58 & 0,30 & 0,32 \\
St2 & 2234 & 1,68 & 0,25 & 0,35 \\
St3 & 1528 & 1,43 & 0,29 & 0,31 \\
St4 & 2575 & 1,55 & 0,30 & 0,30 \\
\hline
\end{tabular}

Berdasarkan hasil analisis dari keempat stasiun nilai indeks keseragaman (E) pada Perairan Mayangan berada pada rentang $\mathrm{E}<0,4$ dapat diindikasikan memiliki keseragaman yang rendah. Nilai keseragaman tertinggi berada pada stasiun 2 yaitu sebesar 0,35 dan terendah sebesar 0,30 pada stasiun 4. Semakin rendah nilai indeks keseragaman, maka semakin kecil pula keseragaman pada populasi sehingga dapat diindikasikan bahwa terdapat dominansi spesies pada populasi terhadap spesies lainnya [24].

\section{Hubungan Parameter Lingkungan dengan Struktur Komunitas Fitoplankton}

Dinamika perubahan struktur komunitas fitoplankton di alam sangat dipengaruhi oleh parameter lingkungan. Pada penelitian ini dilakukan uji korelasi yang menghubungkan parameter lingkungan dengan kelimpahan fitoplankton.

Berdasarkan hasil analisis diketahui bahwa parameter kecerahan memiliki nilai signifikansi sebesar $0,014 \quad(<0,05)$ dan koefisien korelasi 0,686, sehingga variabel kecerahan berpengaruh dan memiliki hubungan yang sedang terhadap kelimpahan fitoplankton. Kecerahan suatu perairan erat kaitannya dengan proses fotosintesis yang dilakukan fitoplankton. Menurut [26], kecerahan suatu perairan akan mempengaruhi laju fotosintesis yang dilakukan oleh fitoplanton dan penetrasi cahaya yang masuk kedalam suatu perairan. Hal ini sejalan dengan pendapat dari [27] yang menyatakan bahwa cahaya yang masuk kedalam perairan menjadi sumber energi bagi fitoplankton untuk berfotosintesis sehingga kecerahanan yang tinggi menjadi syarat untuk berlangsungnya fotosintesis fitoplankton yang optimum.

Sementara untuk parameter lainnya seperti suhu, salinitas, $\mathrm{pH}$, nitrat, dan fosfat 
memiliki nilai signifikansi lebih besar daripada 0,05 . Hal ini menunjukkan bahwa parameterparameter tersebut tidak memiliki hubungan secara langsung terhadap kelimpahan fitoplankton. Menurut [16] terdapat dua variasi faktor lingkungan yang mempengaruhi pertumbuhan fitoplankton di alam yaitu bersifat langsung dan tidak langsung.

\section{Analisis Clustering}

Hasil analisis klaster yang telah dilakukan menunjukkan stasiun 1 membentuk cabang tersendiri. Sedangkan stasiun penelitian lainnya memiliki kesamaan yang lebih tinggi antar stasiun (Gambar 3). Stasiun 1 lokasinya berada di area kawasan pelabuhan yang sangat dipengaruhi oleh aktifitas manusia. Pada stasiun ini juga diketahui memiliki nilai fosfat dan kelimpahan fitoplankton tertinggi. Buangan limbah organik yang tinggi dapat memicu kadar fosfat perairan dan memicu ledakan fitoplankton berbahaya [28].
Selanjutnya berdasarkan hasil dendogram (Gambar 3) stasiun 2 dan 3 memiliki tingkat kemiripan, begitu pula dengan stasiun 4 memiliki tingkat kesamaan yang lebih besar dengan kedua stasiun tersebut. Stasiun 2 dan 3 terletak di lokasi yang berdekatan yaitu pada beberapa daerah daerah penangkapan ikan, maka nilai kualitas perairan serta kelimpahan fitoplankton yang diperoleh pada stasiun ini relatif sama. Selanjutnya pada stasiun 4 terletak di area budidaya perikanan (tambak) dan tentunya kualitas perairan sangat dipengaruhi oleh aktifitas tambak. Kegiatan antropogenik sangat mempengaruhi kualitas perairan, semakin tinggi aktivitas manusia maka semakin tinggi potensi pencemaran [19].

Berdasarkan hasil tersebut dibutuhkan upaya pengendalian dan perlindungan kualitas air secara menyeluruh dan lebih mengikat, terutama untuk kawasan perairan pelabuhan. Seperti penambahan parameter pamantauan nitrat dan fosfat pada peraturan untuk menjamin kelestarian berkelanjutan.

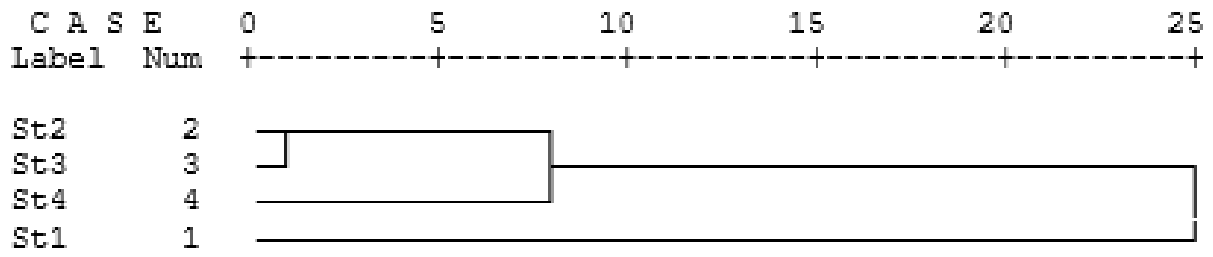

Gambar 3. Hasil analisis clustering masing-masing stasiun penelitian. Analisis klaster menggunakan metode Average Linkage (Between Groups)

\section{KESIMPULAN}

Hasil pemantauan kualitas air pada Perairan Mayangan diketahui secara umum masih sesuai dengan standar baku mutu perairan yang telah ditetapkan. Namun terdapat dua parameter yang tidak termasuk faktor yang diamati pada baku mutu kualitas perairan pelabuhan yaitu nitrat dan fosfat, namun memiliki pengaruh besar terhadap densitas fitoplankton. Terdapat empat divisi fitoplankton yang diidentifikasi pada penelitian ini yaitu Bacillariophyta, Dinoflagellata, Cyanophyta, dan Ochrophyta. Kelas Bacillariophyceae memiliki jumlah genus terbanyak dan didominasi oleh genus Skeletonema dan Chaetoceros. Kedua genus ini termasuk dalam kelompok Harmful Alga Blooms (HAB).
Berdasarkan hasil yang telah didapatkan tersebut monitoring secara rutin dan terus menerus merupakan langkah yang perlu dilakukan dalam pemantauan kesehatan perairan Perairan Mayangan dan sekitarnya. Hal ini bertujuan untuk menjamin keberlangsungan kegiatan perikanan pada wilayah tersebut.

\section{UCAPAN TERIMA KASIH}

Terima kasih disampaikan kepada semua pihak yang telah mendukung terlaksananya penelitian ini. Terima kasih juga disampaikan kepada KEMENRISTEK-DIKTI. Penelitian ini merupakan bagian dari penelitian yang didanai oleh KEMENRISTEK-DIKTI No. 167/SP2H/LT/DPRM.2019, No. Kontrak 330.53/UN10.C10/PN/201. 


\section{DAFTAR PUSTAKA}

[1] R. Zakaria, A. D. P. Fitri, and S. D. Pramitasari, "Analisis Panjang Jaring Dan Ukuran Kapal Terhadap Hasil Tangkapan Alat Tangkap Purse Seine Di Pelabuhan Perikanan Pantai (PPP) Mayangan, Kota Probolinggo, Jawa Timur," vol. 6, p. 8, 2017.

[2] A. Sartimbul et al., "Variasi Komunitas Plankton Dan Parameter Oseanografi Di Daerah Penangkapan Ikan Pelagis Di Perairan Malang Selatan, Jawa Timur," $J F M R$, vol. 1, no. 2, pp. 55-64, Oct. 2017 , doi: 10.21776/ub.jfmr.2017.001.02.2.

[3] D. J. Mackey, J. Blanchot, H. W. Higgins, and J. Neveux, "Phytoplankton abundances and community structure in the equatorial Pacific," Deep Sea Research Part II: Topical Studies in Oceanography, vol. 49, no. 13-14, pp. 2561-2582, Jan. 2002, doi: 10.1016/S0967-0645(02)00048-6.

[4] Yuliana, "Distribusi dan Struktur Komunitas Fitoplankton di Perairan Jailolo,Halmahera Barat," vol. 6, no. 1, pp. 41-48, 2015.

[5] D. Sulistiowati, R. H. R. Tanjung, and D. Lantang, "Keragaman dan Kelimpahan Plankton Sebagai Bioindikator Kualitas Lingkungan di Perairan Pantai Jayapura," p. 18, 2016.

[6] M. Rumanti, S. Rudiyanti, and M. N. Suparjo, "Hubungan Antara Kandungan Nitrat Dan Fosfat Dengan Kelimpahan Fitoplankton Di Sungai Bremi Kabupaten Pekalongan," vol. 3, p. 9, 2014.

[7] W. Indriani and S. Hutabarat, "Status Trofik Perairan Berdasarkan Nitrat, Fosfat, Dan Klorofil-A Di Waduk Jatibarang, Kota Semarang," vol. 5, p. 7, 2016.

[8] R. F. Sihombing, "Kandungan Klorofil-a Fitoplankton di Sekitar Perairan Desa
Sungsang Kabupaten Banyuasin Provinsi Sumatera Selatan," vol. 5, pp. 34-39, 2013.

[9] L. D. Talley, Encyclopedia of global environmental change, vol. 1. 2002.

[10] D. Salim, Y. Yuliyanto, and B. Baharuddin, "Karakteristik Parameter Oseanografi Fisika-Kimia Perairan Pulau Kerumputan Kabupaten Kotabaru Kalimantan Selatan," j.eng, vol. 2, no. 2, pp. 218-228, Sep. 2017, doi: 10.31186/jenggano.2.2.218-228.

[11] M. C. Mainassy, "The Effect of Physical and Chemical Parameters on the Presence of Lompa Fish (Thryssa baelama Forsskål) in the Apui Coastal Waters of Central Maluku District," JFS, vol. 19, no. 2, p. 61, Aug. 2017, doi: $10.22146 /$ jfs. 28346 .

[12] E. Nurmala and E. Utami, "Analisis Klorofil-A Di Perairan Kurau Kabupaten Bangka Tengah,” vol. 11, p. 8, 2017.

[13] H. P. Hutagalung, "Pengaruh Suhu Air Terhadap Kehidupan Organisme Laut," no. 4, p. 12, 1988.

[14] A. Choirun, S. H. J. Sari, and F. Iranawati, "Identifikasi Fitoplankton Spesies Harmfull Algal Bloom (HAB) Saat Kondisi Pasang Di Perairan Pesisir Brondong, Lamongan, Jawa Timur," vol. 25, p. 9, 2015.

[15] H. Meirinawati and M. Muchtar, "Fluktuasi Nitrat, Fosfat dan Silikat di Perairan Pulau Bintan," segara, vol. 13, no. 3, Jun. 2017, doi: 10.15578/segara.v13i3.6493.

[16] C. S. Reynolds, The Ecology of Phytoplankton. Cambridge: Cambridge University Press, 2006.

[17] C. M. Lalli and T. R. Parsons, Biological oceanography: an introduction, 2. ed., Reprinted. Amsterdam: Elsevier Butterworth-Heinemann, 2006. 
[18] Kurniawan, A. I. S. Purwiyanto, and Fauziyah, "Hubungan Nitrat, Fosfat Dan Ammonium Terhadap Keberadaan Makrozoobentos Di Perairan Muara Sungai Lumpur Kabupaten Ogan Komering Ilir Sumatera Selatan,” vol. 2, pp. 101-110, 2016.

[19] K. Davidson, R. J. Gowen, P. J. Harrison, L. E. Fleming, P. Hoagland, and G. Moschonas, "Anthropogenic nutrients and harmful algae in coastal waters," Journal of Environmental Management, vol. 146, pp. 206-216, Dec. 2014, doi: 10.1016/j.jenvman.2014.07.002.

[20] J. L. Sarmiento, R. D. Slater, J. Dunne, A. Gnanadesikan, and M. R. Hiscock, "Efficiency of small scale carbon mitigation by patch iron fertilization," Biogeosciences, vol. 7, no. 11, pp. 35933624, Nov. 2010, doi: 10.5194/bg-73593-2010.

[21] E. A. Nurcahyani, S. Hutabarat, and B. Sulardiono, "Distribusi Dan Kelimpahan Fitoplankton Yang Berpotensi Menyebabkan Habs (Harmful Algae Blooms) Di Muarasungai Banjir Kanal Timur, Semarang," vol. 5, p. 10, 2016.

[22] N. Lathifah, J. W. Hidayat, and F. Muhammad, "Struktur Komunitas Fitoplankton sebagai Dasar Pengelolaan Kualitas Perairan Pantai Mangrove di Tapak Tugurejo Semarang,” p. 7, 2016.
[23] D. Aliviyanti, S. Suharjono, and C. Retnaningdyah, "The Impact of Dissolved Nitrate and Phosphate on Maximum Growth Rate and Carrying Capacity of Oscillatoria in Intensive Shrimp (Litopenaeus vannamei) Farming Pond Situbondo, East Java, Indonesia," JELS, vol. 7, no. 1, pp. 55-60, Jun. 2017, doi: 10.21776/ub.jels.2016.007.01.11.

[24] Insafitri, "Keanekaragaman, Keseragaman, Dan Dominansi Bivalvia Di Area Buangan Lumpur Lapindo Muara Sungai Porong," Jurnal KELAUTAN, vol. 3, p. 1, 2010.

[25] E. Weliyadi, "Identifikasi Spesies Fitoplankton Penyebab," p. 9, 2013.

[26] S. Sachoemar I and N. Hendiarti, "Struktur Komunitas Dan Keragaman Plankton Antara Perairan Laut Di Selatan Jawa Timur, Bali Dan Lombok," p. 6, 2006.

[27] Y. E. Liwutang, F. B. Manginsela, and J. F. Tamanampo, "Phytoplankton Density and Diversity in the Waters around the Reclamation Area in Manado Beach," PLATAX, vol. 1, no. 3, p. 109, Aug. 2013, doi: 10.35800/jip.1.3.2013.2568.

[28] M. L. Wells et al., "Harmful algal blooms and climate change: Learning from the past and present to forecast the future," Harmful Algae, vol. 49, pp. 68-93, Nov. 2015, doi: 10.1016/j.hal.2015.07.009. 